\title{
REDEFINING RELIGIOUS TRUTH AS A CHALLENGE FOR PHILOSOPHY OF RELIGION
}

\author{
PETER JONKERS \\ Tilburg School of Catholic Theology
}

\begin{abstract}
One of the most important features of contemporary Western societies is the rise of (religious) pluralism. Whereas (philosophical) theism used to serve as a common ground to discuss the truth-claims of religion, this approach seems to have lost much of its plausibility. What I want to argue in this article is that philosophy of religion as a critical intellectual activity still cannot do without the notion of religious truth, but also that it needs to redefine this truth in an existential way, i.e. by interpreting religions as concrete ways of life. In this paper I develop this idea of religious truth by interpreting religions as traditions of wisdom, being a kind of truth that is able to orientate humans' lives without being swayed by the issues of the day. In order to substantiate my interpretation I discuss three fundamental aspects of wisdom, viz. the fact that it rests on a broadened idea of reason, the way in which it discovers the universal in the particular, and the insight that all life-orientations are based on a principle that is subjectively adequate, but objectively inadequate (Kant).
\end{abstract}

\section{INTRODUCTION}

For many philosophers, the rise of (religious) pluralism is one of the most important features of contemporary Western society. This phenomenon has resulted in an enormous boost of the philosophical interest in religious matters, far beyond the traditional disciplinary borders of philosophy of religion. But the rise of religious pluralism has in its turn changed the agenda of philosophy of religion quite dramatically: in order to participate in the current academic and public debate philosophy of religion has to give up one of its traditional theorems, viz. that all Christian denominations are eventually nothing but the offspring of 
one and the same natural religion, whose truth can be demonstrated unambiguously by human reason. According to Habermas and Rawls this foundationalist approach of religion belongs to a metaphysical past, in particular that of natural or rational theology, and needs to be replaced by a more descriptive approach that departs from religion as a social reality. These authors brand the idea of religious truth as intrinsically authoritarian and resulting in oppressing the essential pluralist character of modern societies, and hence this idea needs to be replaced by notions like an (overlapping) consensus or by a post-metaphysical justification of political rule.

However, in my view the notion of religious truth cannot be dismissed so easily at all; on the contrary, I expect it to dominate, often in the form of fundamental rights and essential values, the academic debate, including that among philosophers of religion, as well as the public debate in the years to come. First of all, the notion of religious truth has always been fundamental in at least two world religions, Christianity and Islam; hence it is very unlikely that their present-day adherents will be willing to drop it altogether. Secondly, far beyond the intra-confessional disputes about religious orthodoxy, the idea of religious truth is obviously at odds with the pluralism of contemporary society. Hence the latter cannot escape the question which public expressions of these truths are contradicting its own essential values, and which ones are to be tolerated or even welcomed as a contribution to what holds society together. Thirdly, although Habermas and Rawls reject the idea of religious truth, they explicitly recognize that all great religious traditions are treasuries of true wisdom, thereby implicitly referring to another dimension of religious truth than the authoritarian or oppressive one.

So, in view of these intricate issues I think that one of the most important challenges for philosophy of religion in the years to come consists in redefining the notion of religious truth in such a way that it makes sense and can be discussed in the context of pluralist democracies. Interestingly, the question of the truth-claims of Christian religion has been a shared point of interest between analytical philosophy of religion (especially theism) and those continental philosophers, who are convinced that these kinds of metaphysical questions rather have to be redefined than dismissed altogether. In this paper I shall first give an analysis of the theistic idea of religious truth and explain why it has lost a great deal of its plausibility. Thereafter I shall try to redefine religious truth as an expression of wisdom, and argue that such an approach may 
offer a new common ground that is compatible with the pluralism of our times. In the course of my paper it will become clear that a redefinition of religious truth inevitably implies that philosophy of religion needs to take a new direction too.

\section{THE LOSS OF PLAUSIBILITY OF THE THEISTIC IDEA OF RELIGIOUS TRUTH}

In this paper I use the term 'theism' not in its general sense, namely the belief in the (Christian) God, but in a much more specific way as a philosophical theory about God's existence and his essential attributes. It originated in the $16^{\text {th }}$ century as an intellectual attempt to help put an end to the religious controversies that resulted from diverging interpretations of Scripture on purely doctrinal grounds. Furthermore theism was to serve as a philosophical reply to the rise of atheism and scepticism during the Renaissance and early Enlightenment. ${ }^{1}$ The central claim of theism concerns the existence of God as 'a person without a body (i.e. a spirit) who is eternal, free, able to do everything, knows everything, is perfectly good, is the proper object of human worship and obedience, the creator and sustainer of the universe. ${ }^{2}$ These sentences are not to be seen as expressing attitudes or commending ways of life, but make 'claims about how things are. ${ }^{3}$ Precisely this aspect highlights the philosophical and in particular cognitive character of theism, implying that its concept of religious truth rather belongs to the domain of natural or rational theology than to that of revealed religion. Even more so, in a theistic sense the truth or falsehood of the statement 'I believe in God, Creator of heaven and earth' differs not qualitatively but only in degree from the statement 'I believe it is not going to rain this afternoon' being true or false. ${ }^{4}$ The basic components of theism are threefold. First it presents

1 Ingolf Dalferth, 'The Historical Roots of Theism', in Svend Andersen (ed.), Traditional Theism and its Modern Alternatives (Acta Jutlandica LXX:1 Theology Series 18), (Aarhus: Aarhus University Press, 1994), p. 15. See also: Christoph Schwöbel, 'After "Post-Theism", in ibid., pp. 173-178; and Peter Jonkers, 'Religious Truth in a Globalising World, in Philip Quadrio and Carol Besseling (eds.), Religion and Politics in the New Century: Contemporary Philosophical Perspectives (Sydney: Sydney University Press, 2009), pp. 182-189.

${ }^{2}$ Richard Swinburne, The Coherence of Theism (Oxford: Clarendon Press, 1977), p. 1.

${ }^{3}$ Richard Swinburne, The Coherence of Theism, p. 37.

${ }^{4}$ Han Adriaanse, 'After Theism', in: Svend Andersen (ed.), Traditional Theism and its Modern Alternatives, p. 132. 
a philosophically coherent concept of God, being the true common ground of all particular religious confessions, so that this concept can bridge the gap between the opposing doctrinal views and convictions of the latter. ${ }^{5}$ Second, the coherence of this concept of God serves as the point of departure for demonstrating the existence of God, which is necessary for the truth of some further theistic beliefs; in particular that God is the unique creator and sustainer of the universe. A third characteristic of theism is its preoccupation with finding a solution to the problem of evil. Because theism claimed to offer a theoretical explanation of all states of affairs in the world, the problem of evil and its solution became a central issue as well, which was dealt with by theodicy. It is important to note that the solutions offered by theodicy were strictly theoretical, thereby showing their fundamental difference from more existential approaches of the perennial question of how to deal with evil. ${ }^{6}$

Ever since its origin the project of theism has been confronted with criticisms stemming both from philosophy and theology. From the perspective of the history of philosophy one can refer to the epistemological critique of Hume and Kant, stating that human understanding's aim to know the supersensible only produces (transcendental) illusion. Furthermore there is the critique stemming from contemporary continental philosophy, interpreting theism as the apex of onto-theology, i.e. as having reduced the discontinuous and contingent history of being to an all-encompassing and coherent grand narrative. From a theological perspective theism has been accused of negating the unbridgeable gap between the concept of God as a philosophical principle and the living God of religious traditions, between the truth or falsehood of a cognitive principle and the existential commitment of religious people to the truth of their faith.

However, in this paper I want to focus on another factor explaining the fate of theism in our times, viz. the gradual decline of its plausibility. Taking this approach means that I want to situate theism in a larger social context, in particular the rise of more radical forms of (religious) pluralism as well as the so-called expressivist turn. This means that I do not agree with those authors who situate theism's plausibility-loss against a still more general background, viz. as an aspect of the decline of religion in Western societies, commonly known as the secularisation-process. ${ }^{7}$

\footnotetext{
${ }^{5}$ Ingolf Dalferth, The Historical Roots of Theism, pp. 28-31.

${ }^{6}$ Christoph Schwöbel, After 'Post-Theism', pp. 177-8.
} 
In my view such a very general explanation does not hold, since it is at odds with the current rise of the enduring importance of religions in contemporary society, comprising such divergent phenomena as the popularity of fundamentalism in some Islamic and Christian communities, the growing influence of non-Christian religious traditions, the astonishing popularity of the World Youth Days and the millions of people attending the beatification of the late Pope John Paul II. Hence the reasons of theism's loss of plausibility have to be more specific and to be found elsewhere.

The most important feature of theism is its 'foundationalism', the idea that it rests on the solid foundation of conclusive, rational argumentation, and thus sees itself entitled to make universal truth-claims about God as the ultimate foundation of the universe. By doing so theism was able to transcend what it considered to be the historical contingencies of the various confessions and provide them with a common ground. It is important to note that this ground is primarily cosmologically orientated. This implies, however, that theism de-contextualises the religious idea of God by abstracting from the various practices of faith and their socio-historic context: the God of theism does not function and does not have to function in the concrete contexts of personal piety or communal worship. ${ }^{8}$

In my view this specific form of foundationalism is responsible for theism's loss of plausibility. By taking a dominantly cosmological approach, i.e. by focusing on God as the creator and sustainer of the universe, it was able to discuss with the dominant scientific interpretations of the cosmos, which were by and large atheistic. But by doing so it has lost out of sight so many other, particularly existential aspects of religion that it is not considered any more as offering an adequate common ground for religious and secular worldviews. First of all theism is, just like modern science, a product of modern rationality. In our times however, there is a growing awareness of the reductionist and even oppressive flip-side of this type of rationality, and its disenchanting effects upon the lives and social environment of people. Secondly, whereas it was one of the most fundamental convictions of modernity that reason, with its characteristics of unity and universality, was able to contain the rise of

\footnotetext{
${ }^{7}$ Han Adriaanse, 'After Theism, pp. 137-139. Adriaanse refers in this context to the influential book of Peter Berger, The Sacred Canopy from 1967, re-edited as: Peter Berger, The Social Reality of Religion (Harmondsworth: Penguin, 1973).

${ }^{8}$ Christoph Schwöbel, 'After "Post-Theism”, p. 179.
} 
pluralism, this belief seems to have dissipated in our times, thus making any appeal to a common, reasonable ground a priori suspicious. Even without going as far as to accept Rorty's radical perspectivism, resulting from his rejection of the idea of objective truth as a common ground for all 'final vocabularies,', one has at least to admit, with Rawls, the reality of a plurality of conflicting and irreconcilable 'comprehensive doctrines', religious and secular, which are affirmed by reasonable people. This leads to the idea of a reasonable pluralism, which means that one has to address all these doctrines as reasonable, even though they may be fundamentally different from one's own. But accepting the reality of pluralism implies that a public and shared basis of justification that applies to all comprehensive doctrines is lacking in democratic society, implying that any judgement as to their truth is doomed to fail. Hence, according to Rawls one has to accept that 'the idea of the reasonable is more suitable as part of the basis of public justification for a constitutional regime than the idea of moral truth. ${ }^{10}$ This means that Rawls still accepts, just like theism, the importance of reasonable argumentation as a common frame of reference for all religions, but also that he accepts the dramatic rise of new forms of radical pluralism as a basic characteristic of advanced modernity; consequently, the universal truth-claims of theism can no longer be accepted as offering the substance of a common ground. Thirdly, theism's aim to abstract the notion of God from its socio-historical context worked quite well as long as the philosophical debate between theists, deists and atheists was focused on the cosmological question of the existence of God as creator and sustainer of the universe, and on theodicy as a theoretical attempt to reconcile the idea of a benevolent God with the existence of evil. But due to the affirmation of ordinary life and the expressivist turn (Taylor) the focus of the philosophical debate has shifted from a theoretical approach, which many people nowadays experience as far-off from their daily lives, towards an analysis of the self-involving and existential character of religious beliefs. ${ }^{11}$

All in all, the growing uneasiness with the reductionism of modern rationality, the effects of the new rise of radical forms of (religious)

\footnotetext{
${ }^{9}$ For a more extensive critique of the consequences of Rorty's position for the idea of religious truth see: Peter Jonkers, 'Religious Truth in a Globalising World', pp. 189-197.

${ }^{10}$ John Rawls, Political Liberalism. Expanded edition (New York: Columbia University Press, 2005), p. 129.

${ }^{11}$ Christoph Schwöbel, 'After "Post-Theism”, p. 185.
} 
pluralism upon the ideas of religious truth and the universality of reason, and the shift from a theoretical to an existential approach of religion are largely responsible for theism's loss of plausibility. What implications does this have for the future of philosophy of religion? First of all theism is not identical with philosophy of religion as such, so that the decline of the former does not necessarily mean the end of the latter. On the contrary, as I showed before there is a growing interest among philosophers, including secular ones, in religious issues, especially concerning its role in a public space. Secondly, against all odds and contrary to a widespread (philosophical) conviction, the idea of religious truth, being a fundamental insight of theism, remains very topical. Fundamentally, religions, including their truth-claims, discourses, rituals and practices must be open to critical interpretation. What has changed since the rise of modernity is that this interpretative process is not limited to the members of a specific religious community, but also concerns those belonging to other religious or secular traditions. ${ }^{12}$ Whereas theology traditionally has taken up responsibility for the first kind of interpretation, a philosophical interpretation of religion nowadays has to include the attempt to translate it into a language that can be understood by people who are not familiar with a specific religious language. ${ }^{13}$

Philosophy of religion's focus on a critical interpretation of religions implies that the idea of religious truth is still of crucial importance in the current debate albeit mostly in an implicit way. However, in comparison with the heyday of theism any such attempt has to depart from the reality of an insurmountable pluralism instead of abstracting from it; only by accepting the fundamental character of this reality can philosophy of religion try to re-establish a common ground for the great variety of religious and secular worldviews. Furthermore it has to accept the fact that the dominant language of contemporary society has become more existential instead of theoretical. Obviously this shift influences the way in which philosophy of religion approaches its subject: nowadays religion is primarily seen as a concrete way of life that is essential for our identity in the sense that it gives an answer to fundamental existential questions, in other words that it helps to put our lives in perspective. In sum, one of the most important challenges for philosophy of religion is to redefine

\footnotetext{
${ }^{12}$ Christoph Schwöbel, 'After “Post-Theism”, p. 186.

${ }^{13}$ Interestingly, Habermas, as well as Rawls, argues that this translation of religious insights into a secular language is essential for their philosophical projects. I refrain from commenting on the discussions that have followed their proposals.
} 
the idea of religious truth in such a way that it takes into account the changing cultural context of our times.

\section{REDEFINING RELIGIOUS TRUTH AS A FORM OF WISDOM}

Redefining (religious) truth within the context of a plurality of existential ways of life means first of all that this kind of truth can only be discovered through a reflection that is closely connected to these ways of life. It comes to the fore through the lives of people for whom expressions like 'God is my Saviour' and 'I place my life under the sign of the risen Christ' really orientate their lives. It is important to note that defining religion in such a way does not mean that it is something completely contingent, standing on the same level as our private funny habits and cultural peculiarities. In spite of the inevitable contingency, implied in all religions and secular worldviews, it is essential to recognise that they all claim truth and that they, in these claims, show major qualitative differences. Hence defining religion as a way of life cannot be used as a way to keep off a critical examination of its truth-claims; this is all the more true since Christianity as well as some other religions and secular worldviews, is essentially a religion of conversion. ${ }^{14}$ Furthermore, especially because the proposed approach takes religion not so much as a theoretical doctrine, but as embedded in concrete existence, it is all the more necessary to be aware of the fact that every way of life, religious as well as secular, is inevitably a mixture of truth and falsehood. But in contrast to the predominantly doctrinal approach of theism an existential approach of religious truth focuses on notions like truthfulness and faithfulness. Finally, although my examples are taken from Christian religion, it is important to note that other religions and secular worldviews can also be treasuries of existential truth and actually claim to be so.

If one wants to determine the notion of existential truth further, the term that is most commonly used is wisdom. In general wisdom can be defined as an encompassing, theoretical and practical kind of knowledge, which is able to give an orientation or perspective to human existence. Wisdom strikes us as an extraordinary kind of knowledge, resting on human experience, but also having a divine origin. ${ }^{15}$ All religions and

\footnotetext{
${ }^{14}$ For a more detailed analysis of this problem see Peter Jonkers, 'Contingent Religions, Contingent Truths?' in Dirk-Martin Grube and Peter Jonkers (ed.), Religions Challenged by Contingency: Theological and Philosophical Perspectives to the Problem of Contingency (Star-series) (Leiden: Brill, 2008), pp. 161-181.
} 
secular worldviews can to a large extent be defined as traditions of wisdom. As to Judaism and Christianity one can refer to the Books of Wisdom and to the sayings of Jesus; but secular world-views too are treasuries of wisdom, and they can be found in the classical works of world-literature and conventional wisdom. Hence wisdom can be qualified as having a trans-cultural, universally human character ${ }^{16}$ which is founded on the fact that all humans have to deal with the perennial questions of their origin and destiny and want to respond to them in an authentic and truthful way. But although this explains that wisdom is indeed universal, it does not mean that all that presents itself as such turns out to be true wisdom. This is where philosophy comes in, which since Socrates has been defined as the quest for wisdom. ${ }^{17}$ Precisely because it strives for true wisdom, it has to examine every pretension of wisdom critically in order to liberate it from self-conceit, ideology, etc. The double, divine and human origin of wisdom means also that philosophy stands always in a relation of approximation with regard to wisdom. Finally, in order to be able to fulfil its task philosophy has to approach wisdom in close relation to the tempo-spatial context in which people live their lives, and not as an abstract kind of knowledge. ${ }^{18}$

Obviously, my proposal to redefine religious truth as wisdom is still very vague. My aim in the remainder of this section is to discuss some of its features as well as their implications for philosophy of religion.

\subsection{Reason and understanding}

First of all, wisdom is based on a much broader kind of rationality than the one that is predominant in modern science, including the social sciences; it also tends to see reality from a broader perspective. In other words, wisdom is the fruit of reason, whereas the scientific truth is the product of understanding. Building on the origins of this distinction in the philosophies of Kant and Hegel one can say that reason is capable of producing 'a self-subsistent unity, in which [...] every member exists for every other, and all for the sake of each, so that no principle can safely be

${ }^{15}$ Andreas Speer, 'Weisheit', in Joachim Ritter, Karlfried Gründer und Gottfried Gabriel (Hrsg.), Historisches Wörterbuch der Philosophie, Band 12 (Darmstadt: Wissenschaftliche Buchgesellschaft, 2004), p. 371.

${ }^{16}$ Andreas Speer, 'Weisheit', p. 371.

${ }^{17}$ Plato, Apology 20 d-e

${ }^{18}$ Willi Oelmüller, 'Der kritische Weg ist allein noch offen', in Willi Oelmüller (hrsg.), Philosophie und Weisheit. Kolloquien zur Gegenwartsphilosophie, Band 12. (Paderborn: Schöningh, 1989), p. 179. 
taken in any one relation, unless it has been investigated in the entirety of its relations to the whole employment of pure reason. ${ }^{19}$ In Hegel's philosophy, this unifying and integrating function of reason is extended to all domains of being. Whereas he defines understanding as 'the capacity to set limits ${ }^{20}$ and hence to produce all kinds of dichotomies, 'the sole interest of reason is to suspend such rigid antitheses.' ${ }^{21}$ Obviously, it is not Hegel's intention to play off reason and understanding against each other: on the contrary, in order to avoid a kind of vague, undifferentiated knowledge or to remain entangled in the irrationality of immediate intuitions and edifying talk it is essential to start with the definitions and distinctions of understanding. ${ }^{22}$

When we apply this distinction to the existential approach of religious truth, as exemplified in traditions of wisdom, it is obvious that wisdom rather belongs to the domain of reason than to that of understanding. Wisdom does not compete with scientific rationality, but asks for the significance of the latter's results for human existence. This insight puts the contemporary debate between science and religion in a completely different perspective: the Christian belief that God is the creator of heaven and earth does not present an alternative to the big-bang theory, but encourages people to believe that our life-world is a place of justice, that this justice is not a human invention or construction, but is willed by God, thus inspiring people to cooperate in fulfilling the ultimate goal of His creation. Obviously, philosophy of religion as a reasonable endeavour has to examine whether this expression of religious wisdom is true. It has to ask why one should refer to a divine kind of justice in the first place instead of relying solely on the justice of established human laws, if the appeal to a transcendent authority does not pave the way for new forms of dogmatism, and if the connection between justice and an all-embracing purposiveness does not lead to totalitarianism, thereby excluding people with other religious or secular convictions.

\footnotetext{
${ }^{19}$ Immanuel Kant, Kritik der reinen Vernunft, B XXIII.

${ }^{20}$ Georg Wilhelm Friedrich Hegel, 'Differenz des Fichteschen und Schellingschen Systems der Philosophie', in Georg Wilhelm Friedrich Hegel, Gesammelte Werke, Band 4: Jenaer kritische Schriften (Hamburg: Meiner Verlag, 1968), p. 12.

${ }^{21}$ Ibid., p. 13.

${ }^{22}$ Cf. Hegel's famous metaphor in which he criticizes the result of this kind of knowledge as the night in which all cows are black. Georg Wilhelm Friedrich Hegel, Phänomenologie des Geistes, in Georg Wilhelm Friedrich Hegel, Gesammelte Werke, Band 9: Phänomenologie des Geistes (Hamburg: Meiner Verlag, 1980), p. 17.
} 
All these questions are existential ones, related to religion's pretension to be a source of true wisdom. In order to be able to answer them it is imperative that philosophy of religion accommodates its approach to the reasonable kind of rationality that is characteristic of wisdom. Only then it can find out if the Christian faith in creation succeeds in giving a truthful orientation to human existence, in other words if it can legitimately claim to offer true wisdom. Anyhow, it is clear that, since religious wisdom and its philosophical examination refer to the whole of human existence as an integrated unity, they are founded on reason and reach far beyond the scope of understanding and scientific rationality.

In a similar vein, redefining religious truth in an existential way and examining its claim to true wisdom philosophically gives a new input to the hotly debated issue if and how religious insights and doctrines can be introduced in the public debate, and if and how they can be translated into a language that can in principle be understood by contemporary, secular society. According to Rawls, 'reasonable comprehensive doctrines, religious and nonreligious, may be introduced in the public political discussion at any time, provided that in due course proper political reasons - and not reasons given solely by comprehensive doctrines - are presented that are sufficient to support whatever the comprehensive doctrines introduced are said to support. ${ }^{23}$ In this context, I am not so much interested in discussing 'when' or 'by whom' Rawls's famous proviso is to be satisfied, nor whether it puts unequal burdens on the shoulders of religious citizens in comparison to secular ones. Instead, I want to focus on the question of what kind of public reasons are required for the political debate and if they are indeed reasonable. Rawls summarizes them as 'a family of reasonable political conceptions of justice', meant to make religious views acceptable to a broader audience. ${ }^{24}$ But it is highly questionable if, in the current climate of a growing dominance of scientific rationality over all sectors of the life-world, Rawls's proposal can avoid the risk that religions are forced to comply with the standards of scientific rationality in order to be accepted by a broader audience, which would exclude a fair discussion about their acceptability as reasonable comprehensive doctrines. Moreover, this risk not only applies to religions, but also to secular traditions of wisdom. In my view Rawls

\footnotetext{
${ }^{23}$ John Rawls, Political Liberalism. Expanded edition (New York: Columbia University Press, 2005), p. 462.

${ }^{24}$ Ibid., p. 463.
} 
underestimates the disenchanting and distorting effects of scientific rationality on religious as well as secular ways of life. When put in this situation, people who consider these traditions as sources of wisdom feel disrespected and not taken seriously, since they are forced to justify themselves before a tribunal that is biased, because it is based on a kind of rationality that is completely at odds with the existential truth that these traditions express. One only needs to refer to the tendency of scientific rationality to 'naturalise' human existence, which makes it almost impossible for these traditions of wisdom to reasonably argue what it means to see humans primarily as persons.

In sum, the distinction between understanding and reason may prove to be helpful to enable religions and secular world-views presenting themselves not as irrational ways of life, but as expressions of wisdom, claiming to give a truthful orientation to human life. Obviously, philosophy of religion has to examine whether these claims are legitimate, but without laying them on the Procrustean bed of scientific rationality. Rather, it interprets them as reasonable, i.e. as offering an integral perspective on human existence, thereby enabling these traditions to be discussed on their own terms. Finally, approaching religions and secular world-views as expressions of wisdom provides them with a common ground, which is essential to prevent reasonable pluralism from degenerating into its arbitrary, postmodern variant. ${ }^{25}$

\subsection{Particularity and universality}

Secondly, defining religious traditions as (particular) ways of life that claim to express (universal) wisdom requires reconsidering the conception of the relation between these two concepts. Trying to make sense of religious truth in a context of radical plurality presupposes first of all that one refrains from lumping together all these expressions of (religious) wisdom as equally contextual and hence particular without any discrimination as to the legitimacy of their respective truth-claims. Apart from the fact that such an approach is philosophically very dissatisfying it fails to contribute in a meaningful way to the current debate of the role of religion in the public sphere. But on the other hand, the approach of traditional metaphysics, including theism, consisting in laying bare the universal, theoretical truth-claims of religions and secular

${ }^{25}$ Rawls too distinguishes between reasonable pluralism and pluralism as such. See: John Rawls, Political Liberalism. Expanded edition, pp. 36-7. 
world-views by abstracting as much as possible from the particularity and contingency in which they are embedded, does not work either. As we have seen above, this approach has contributed largely to theism's loss of plausibility. Hence it is a major challenge for philosophy of religion to try out an alternative approach of the relationship between particularity and universality. This could lie in developing a kind of metaphysics, which starts hermeneutically, that is from the recognition that religions and secular world-views are primarily concrete ways of life, embedded in the particular history of (religious) communities. But as metaphysics it remains loyal to the idea of religious truth, trying to approximate it by critically examining how these traditions respond to the perennial questions about the origin and destiny of humankind. To give only one historic example of this approach among many others: in his moral philosophy F.H. Jacobi sets out to depart from concrete life-stories, in which persons do not so much demonstrate, but rather testify to the truth of their basic beliefs, thereby criticising the abstract universality and the impersonal character of Kant's moral philosophy. ${ }^{26}$

How does this hermeneutical metaphysics deal with the relation between particularity and universality in connection to religious truth? In accordance with the nature of this approach, let us start with a concrete example of Christian wisdom, viz. the prayer for forgiveness in the Our Father: 'Forgive us our debts, as we also have forgiven our debtors.'27 The question then is if this particular expression of wisdom relates to existential truth, and hence can legitimately claim (a certain degree of) universality. The existential truth of the prayer for forgiveness lies in the fact that it links the horizontal moral obligation to forgive one's debtor to a vertical dimension, the beneficial experience that humans, however sinful they may be, can trust on the promise that God forgives their debts against him, which are infinitely greater. This inspires Christians to go as far as to forgive the unforgivable. According to a contemporary secular philosopher as Derrida, this is basically what forgiveness is all about: a pure gift without the guarantee of a return. In other words, the basic experience that our sinful existence is mercifully accepted by God makes it legitimate that he demands from us, not to forgive our brothers and sisters seven times, 'but seventy times seven times', that

${ }^{26}$ Friedrich Heinrich Jacobi, Werke. Gesamtausgabe, Band 1: Schriften zum Spinozastreit (Hamburg: Meiner Verlag, 1998), pp. 131-2.

${ }^{27}$ Matthew 6:12. 
is to forgive infinitely. ${ }^{28}$ Thus, the existential truth of this expression of Christian wisdom lies in the fundamental anthropological insight that the vertical dimension of forgiveness (the experience of God's mercy) may be essential for humans to be able to forgive even the unforgiveable or to forgive infinitely (the horizontal dimension). This is not to say that only Christians are able to forgive, but points to the universal meaning of a particular tradition.

In a similar vein Habermas has argued that particular religious traditions often express normative truths, in which a secular society can recognise universal moral intuitions, with which it has lost contact in the course of time. He illustrates this by means of the biblical story of God's creation of man: 'God created man in his own image; in his own image He created him. ${ }^{29}$ This religious belief expresses the idea that God, as a God of love, created Adam and Eve as free beings, similar to, but at the same time absolutely different from Him: 'God remains a "God of free men" only as long as we do not level out the absolute difference that exists between the creator and the creature. ${ }^{30}$ Habermas takes this particular religious insight to express a fundamental normative truth, the dignity of every human being, and uses it to criticise the social and moral effects of gen-technology. When this technology is applied to humans, it indeed erases this difference between creator and creation, thus entailing fatal consequences for humanity as such:

One need not believe in theological premises in order to understand what follows from this, namely, that an entirely different kind of dependence, perceived as a causal one, becomes involved if the difference [between God and man] assumed as inherent in the concept of creation were to disappear and the place of God be taken by a peer - if, that is, a human being would intervene, according to his own preferences and without being justified in assuming, at least counterfactually, a consent of the concerned other, in the random combinations of the parents' sets of chromosomes. [...] Would not the first human being to determine, at his own discretion, the natural essence of another human being at the same time destroy the equal freedoms that exist among persons of equal birth in order to ensure their difference? ${ }^{31}$

\footnotetext{
${ }^{28}$ Matthew 18:21.

${ }^{29}$ Genesis 1:27.

${ }^{30}$ Jürgen Habermas, 'Faith and Knowledge', in Idem, The Future of Human Nature (Cambridge: Polity Press, 2003), pp. 114-5.
} 
In my view both the above examples are illustrations of a promising approach of the relation between the particularity of religious traditions and their claim to express true wisdom. Apparently, religious wisdom not only orientates the lives of the members of a specific religious community, but can also have a fundamental significance for other people, including secular ones. Far from suggesting that this approach solves all problems regarding religious truth in the context of a radical plurality of religions and secular world-views, it at least enables the latter to participate in the public debate without being marginalised a priori as a particular, biased position. This gives an interesting twist to the statement that contemporary society is post-secular: it is not only post-secular because religion, as a matter of fact, has not disappeared from the public scene, but also because particular religious traditions are the bearers of fundamental moral intuitions, which otherwise could be lost: 'Philosophy has good reasons to be willing to learn from religious traditions.'32

\subsection{Wisdom and truth}

A final and perhaps most fundamental aspect of the suggestion to redefine the idea of religious truth in an existential way concerns the question of how exactly it is related to (religious) traditions as expressions of wisdom. As already pointed out above, Plato defined philosophy as a critical examination of the truth of wisdom, a definition which has become paradigmatic. However, since the rise of science and its impact on philosophy the latter's relation to wisdom has changed dramatically. Since then philosophy's only remaining option to examine the truth of wisdom has been to apply the critical and methodological rigor of science. The conclusion of Kant's Critique of Practical Reason offers an excellent illustration of this shift:

Science (critically undertaken and methodically directed) is the narrow gate that leads to the true doctrine of practical wisdom [...]. Philosophy must always continue to be the guardian of this science; and although the public does not take any interest in its subtle investigations, it must take an interest in the resulting doctrines, which such an examination first puts in a clear light. ${ }^{33}$

\footnotetext{
${ }^{31}$ Ibid., p. 115.

32 Jürgen Habermas, 'Pre-political Foundations of the Democratic Constitutional State, in Jürgen Habermas and Joseph Ratzinger, The Dialectics of Secularization: On Reason and Religion (San Francisco: Ignatius Press, 2006), p. 42.
} 
Although some contemporary philosophers agree with Kant's thesis that science is the indispensable 'organon' for philosophy in order to be able to separate true wisdom from fanaticism ('Schwärmerei'), ${ }^{34}$ I have shown above that the type of rationality that predominates science is too restricted to be able to critically account for the truth-claims of wisdom.

Instead of following Kant's suggestion to use science to pass a massive and final judgment about the truth of wisdom I want to take another approach and focus on the life-orientating character of wisdom. The advantage of this approach is that it explicitly links wisdom to the concrete existence of humans, thereby accepting that there is a plurality of ways to give orientation to one's life, but at the same rejecting the idea that every orientation is all the same, in other words that there would be no qualitative differences between various traditions of wisdom, and that one could not argue reasonably about their truth. In order to develop the idea of a reasonable discussion concerning the truth of various life-orientations I want to start from a text of Kant's in which he explicitly addresses this issue, viz. What Does It Mean: to Orientate Oneself In Thinking? ${ }^{35}$ Kant wrote this essay as a reaction to the pantheism-controversy of 1785, opposing Mendelssohn, the most illustrious representative of the German Enlightenment, and Jacobi, who was generally seen as defending the position that truth is the result of immediate revelation. It is not my intention here to offer a detailed historical account of the ins and outs of this controversy and Kant's position in it, but to examine from a systematic perspective how he answers the question of how one can orientate oneself truthfully in moral matters. ${ }^{36}$

${ }^{33}$ Immanuel Kant, 'Kritik der praktischen Vernunft', in Immanuel Kant, Werke in zehn Bänden, Herausgegeben von Wilhelm Weischedel, Band 6: Schriften zur Ethik und Religionsphilosophie: Erster Teil (Darmstadt: Wissenschaftliche Buchgesellschaft, 1968), p. 302. See also: Immanuel Kant, 'Logik', in Immanuel Kant, Werke in zehn Bänden. Band 5: Schriften zur Metaphysik und Logik, p. 449: 'For science is of an intrinsic value as an organon of wisdom only. But, as such, it is indispensable to it; so that it may well be maintained that wisdom without science is a shadow of a perfection which we never shall reach.'

${ }^{34}$ Ludger Honnefelder, 'Weisheit durch den Weg der Wissenschaft. Theologie und Philosophie bei Augustinus und Thomas von Aquin', in Willi Oelmüller (hrsg.), Philosophie und Weisheit: Kolloquien zur Gegenwartsphilosophie, Band 12 (Paderborn: Schöningh, 1989), p. 77; Willi Oelmüller, 'Der kritische Weg ist allein noch offen', in Willie Oelmüller (hrsg.), Philosophie und Weisheit, pp. 174-177.

${ }^{35}$ Immanuel Kant, 'Was heißt: sich im Denken orientieren?' in Immanuel Kant, Werke in zehn Bänden. Band 5: Schriften zur Metaphysik und Logik, pp. 267-283. 
In his search for a principle that could orientate us in (our thinking about) moral matters Kant agrees neither with Mendelssohn nor with Jacobi: common sense is unable to guide us in moral matters, since it is too ambivalent (against Mendelssohn), but renouncing reason completely by relying on an 'effusive intuition under the name of faith to which tradition or revelation can be grafted on without the consent of reason, ${ }^{37}$ as Jacobi did, is even more problematic, since it only leads to fanaticism. On the contrary, being able to reasonably examine the truth of one's orientation in life is an essential and necessary human capacity. So he calls on everyone to 'accept whatever seems most credible to you after careful and honest examination [...]; but do not deny reason that prerogative which makes it the greatest good on earth, namely its right to be the ultimate touchstone of truth. ${ }^{38}$ However, the kind of reason that Kant has in mind is not the pre-critical, dogmatic reason of the Enlightenment-philosophers (including Mendelssohn), which claimed to possess an objective, quasi scientific knowledge of truth in moral issues; herewith he rules out a theistic answer right from the start. Instead of the two aforementioned extremes Kant suggests that 'the extended and more precisely defined concept of orientating oneself can be helpful to elucidate the maxim of healthy reason in its activities to attain cognition of super-sensible objects. ${ }^{39}$

Kant's argument about orientating oneself in thinking is especially relevant for the current debate because he accepts the reality of (religious) pluralism: orientation is always linked to the specific, subjective position of a person or a community in a given moral landscape. But at the same time he holds on to humanity's fundamental need to reasonably examine the truth of their life-orientations, thereby admitting that they are not all the same. Moreover the concept of orientating oneself in thinking qualifies in a most interesting way what it means to reason about moral issues in concrete, lifelike situations. Although the content of the idea of moral orientation will be developed in the next paragraphs, it is already clear at this stage that every orientation, because of the subjective aspect it involves, differs from the conviction that the objective truth of one's faith is guaranteed, because it is the result of an immediate inspiration

\footnotetext{
${ }^{36}$ For an historical analysis of this essay cf. Gerd Irrlitz, Kant-Handbuch. Leben und Werk (Stuttgart: Metzler, 2002), pp. 419-422.

${ }^{37}$ Immanuel Kant, 'Was heißt: sich im Denken orientieren?', p. 268.

${ }^{38}$ Ibid., p. 283.

${ }^{39}$ Ibid., pp. 268-9.
} 
of the divine, as well as from the position that claims to be able to demonstrate the truth of life-orientations with the help of a completely disengaged, so to speak, scientific rationality. Reasoning about the truth of one's life-orientation is fine and even necessary, but has to depart from the existential situation one finds oneself in.

Every kind of orientation requires a subjective principle: if one wants to orientate oneself geographically, the awareness of the difference between one's left and right hand is essential to find out, when one knows that it is midday, where the sun has risen. By analogy, to orientate oneself in thinking means 'to be guided, in one's conviction of truth, by a subjective principle of reason where objective principles of reason are inadequate. ${ }^{\prime 0}$ Such a guidance is especially necessary in existential or moral situations, because we feel on the one hand an urgent (subjective) need to pass a true judgment about our life-orientations, while on the other we are painfully aware of the lack of objective knowledge that would make such a judgment univocally and universally true. In other words, to orientate oneself in moral questions is neither a matter of just doing whatever come to one's mind, nor of objective science. Therefore, just as in a geographical orientation we then need an orienting principle, in the light of which a judgment can be passed. But characteristic for an orientation in thinking is that this principle is not a sensuous one, but is inherent in reason itself. Obviously philosophy has to examine critically if this principle is not contradictory and if it, as a supersensible principle, can suitably be related to our reasoning about the experienced world. So, whenever we orientate ourselves in thinking 'the right of the need of reason supervenes as a subjective ground for presupposing and accepting something which reason cannot presume to know on objective grounds, and hence for orientating ourselves in thinking [...] purely by means of the need of reason alone. ${ }^{41}$

As said, the need of this subjective guiding principle is above all pressing in moral or existential matters; that is, whenever we are confronted with the necessity to judge about e.g. the possibility of reconciling virtue and happiness, freedom and nature. According to Kant this need can only be fulfilled by accepting the objective reality of an original archetypical being, both as the supreme intelligence and the highest good. Although the existence of this being cannot be demonstrated objectively, its

\footnotetext{
${ }^{40}$ Immanuel Kant, 'Was heißt: sich im Denken orientieren?', p. 270, footnote.

${ }^{41}$ Ibid., p. 271.
} 
acceptance is nevertheless essential in order to prevent the highest good as well as morality as a whole from being regarded merely as an ideal. Kant calls this attitude a reasonable belief; it consists in the subjective conviction of the truth of a being on purely reasonable grounds, while at the same time being aware that the existence of this being cannot be demonstrated objectively. This reasonable belief is a conviction of truth which is subjectively adequate, but objectively inadequate. It thus holds an intermediary position between an opinion (which is a subjectively and objectively inadequate conviction of truth) and knowledge (which is a conviction of truth on subjectively and objectively adequate grounds). Thus, 'a pure faith of reason is the signpost of a compass by means of which the speculative thinker can orientate himself on his reasonable wanderings in the field of supersensible objects'. ${ }^{42}$

Kant's analysis of orientating oneself in thinking offers a fascinating elucidation of religion and secular world-views as traditional forms of wisdom and their relation to truth. First of all, the subjective character of the need for wisdom does not mean that every individual could invent or construct it high-handedly, but that it is a basic characteristic of all humans: we have a fundamental need for wisdom, because knowing how to orientate ourselves is essential in all moral, i.e. existential, matters. Because this need is so deeply embedded in our spiritual nature, it is subjectively adequate. In my view this insight in the subjective universality' of the need for wisdom offers the common ground in order to understand the basic anthropological dynamic of religions and secular world-views. The debate between religions and secular world-views it not between irrational faith and objective reason, but between diverging traditions of wisdom, each of them offering its own way to orientate one's life. However, the subjective universality of the need for wisdom does not by itself mean that the objective counterpart of this need is demonstrably true. In this respect Kant says that the best we can reach is a reasonable faith in the reality of the highest good, which is exemplified in the highest being. This being serves as the point of reference, with the help of which we judge the existential truth of our concrete orientations in life. But because of its objective inadequacy it can never serve as a standard that is always at our disposal and can be read unambiguously. Furthermore, from a contemporary perspective it is clear that the object of the pure faith of reason cannot be identified with God as supreme

\footnotetext{
${ }^{42}$ Ibid., p. 277.
} 
intelligence and highest good, as Kant does, since this would rule out secular forms of wisdom a priori. Instead I want to suggest the idea of human dignity as constituting the substance of this subjective principle, since it unites secular as well as religious traditions. It is essential to stress the objective inadequacy of the idea of human dignity, implying that it cannot be identified with the (rather Western and secular) declaration of human rights, but remains open to approaches from various religious and secular, Western and non-Western traditions.

Anyhow, the gap between subjective adequacy and objective inadequacy is essential for all kinds of human wisdom, religious and secular, as it is a consequence of the fact that we are finite beings, lacking a divine knowledge of the world in which we live. But although the truth of human wisdom cannot be demonstrated unambiguously, a reasonable examination of it is nevertheless essential, since from our own experience we know that there are orientations in life that lead us astray. As said above, the basic reason for this approach is that reason and not some divine illumination is the ultimate touchstone of truth.

Following the terminology of the second section of this paper one can call this combination of subjective adequacy and objective inadequacy the plausibility of religion, since plausibility concerns the reasonable acceptability (as distinct from the demonstrable truth) of religion for a subject or community. In sum, as I argued above philosophy of religion should focus on a reasonable argumentation in favour of the plausibility of religion, thereby starting from the common insight that religious and secular ways of life are attempts to orientate people in existential questions.

\section{CONCLUSION}

If philosophers of religion want to try the existential approach to religious truth presented in the previous section, they first of all need to be familiar with what a religious way of life means, just like philosophers of art are required to have some familiarity with art. By accepting this condition, they somehow continue the pre-modern tradition of faithful thinking, of faith searching for understanding, albeit in a totally different context than the one of Anselm, who was one of its founding fathers. This difference primarily concerns the dominance of secular ways of life and the growing presence of non-Christian religious traditions. They make the position of contemporary religious philosophers look similar to the one of the apostle Paul on the Areopagus. Just as Paul had to explain the 
truth of the Christian way of life to epicurean and stoic philosophers, who did not at all share his basic convictions, the task of contemporary philosophers of religion is also to explain the substantially true in the religious way of life they are familiar with, as reasonably as possible, so that it is also intelligible to people not sharing it. 